\title{
EFFECT OF FEEDING SPROUTED BARLEY GRAINS ON RICE STRAW AND OLIVE CAKE ON PERFORMANCE OF GOATS IN SINAI
}

\author{
H.G. Helal \\ Department of Animal and Poultry Nutrition, Desert Research Center, P.O. Code 11753 Mataria, Cairo, \\ Egypt.
}

(Received 20/10/2015, Accepted 30/11/2015)

\section{SUMMARY}

$\mathrm{T}$

The present experiment was aimed to study the effect of sprouted barley grains (Hordeum vulgare L.) on a mixture of olive cake and rice straw (50:50) as a media without (T2) or with $1 \%$ (T3), $2 \%$ (T4), or 3\% (T5) of urea solutions in comparison with the control Alfalfa, (Medicago sativa). All diets were fed ad libitum for 45 days. The experiment was performed on twenty desert male goats (18 months old) with an initial body weight of $24.34 \pm 1.29 \mathrm{~kg}$ randomly divided into five equal groups, (4 animals per group). Five digestibility trials were conducted to evaluate nutrients digestibility and nitrogen balance for experimental roughages. Results showed that the treatments with sprouted barely increased CP content while OM, NDF, ADF and ADL contents were decreased. The highest values of DMI due to the higher palatability for animals fed T5 compared with control group; the same group revealed a significant improvement on CP, EE, NDF and hemicellulose digestibility. The highest TDN\% value was recorded by animals fed T5 (58.55\%) followed by T1, T4, T3 and the lowest value was for T2. Highest $(\mathrm{P} \leq 0.01) \mathrm{DCP} \%$ was $9.24 \%$ which recorded by T1 followed by T5, T4, T3 and T2, respectively. All animals were in positive N-balance but animals fed on $\mathrm{T} 2$ retained the least amount of nitrogen balance $(\mathrm{mg} / \mathrm{kg} \mathrm{BW})$ among treatments. Goats fed sprouted barely grains treated with urea solutions had significantly $(\mathrm{P} \leq 0.01)$ higher total volatile fatty acids and ammonia concentrations in rumen at 3 hours post feeding. In conclusion, goats in T5 recorded the best TDN, DCP and nitrogen balance with normal blood parameters.

Keywords: goats; sprouting barley; olive cake; rice straw; chemical composition; nutritive value; rumen and blood parameters.

\section{INTRODUCTION}

The shortage of animal feeds in Egypt necessitates that intense research efforts should be directed towards exploring the possibility of using new-non conventional sources or agricultural by-products as animal feed and improving their nutritive values (Shoukry et al., 1985) cereal crops generate large amount of organic agricultural waste in many countries. Rice plant (Oryza sativa L.), is one of the most abundant crop in Egypt, 2 million feddans (EEAA, 2008) with an average production of about 6.12 million tons per year and 9.5 tons per hectare in 2005 (FAO, 2011). In Egypt, there are about 30 million tons of agricultural residues available per year. Rice straw is a major crop residue in surplus amounts (Al-Asfour, 2009 and Shoukry, 2013). About 20\% of rice straw was used for other purposes such as ethanol, paper and fertilizers production as well as fodders (El-Gammal and Shakour, 2001) and the remaining part was left on the fields for burning within a period of 90 days (from October to mid-December) get quick rid of the leftover debris. The resulting emissions significantly contribute to the air pollution called the black cloud (Keshtkar and Ashbaugh, 2007). However, rice straw is characterized by low level of CP and high level of structural polysaccharides, which drastically affected the DM intake, digestion and ultimate performance (Wanapat et al., 1985; Chemjon, 1991; Safari et al., 2011). Another problem is that great. Urea treatment may be the most suitable method for small-scale farmers to improve the feed quality of straws (Hanafi et al., 2012). Urea treatment of rice straw could increase its nutritive value, improved overall intake, nutrient digestibility, VFA production and increased passage rate of particles in the rumen (Hart and Wanapat, 1992; Abate and Melaku, 2009). Areas are cultivated by olive trees, especially in Sinai and the North-Western Coast Zone, therefore, there are great amounts of olive by products without beneficial usage and are considered as wastes. In South Sinai, there is a great shortage of animal feedstuffs, while olive cake represents the majority of agro-industrial by-products. About 7440 ton of olive fruits are annually produced and about 640 ton of olive cake remains after oil extraction (Information Center of South Sinai Governorate, 2014). Olive cake could be used for ruminant nutrition, 
but their use is limited because of their low nutritive value (Sansoucy et al., 1985), high NDF and ADF (Nefzaoui, 1983), condensed tannins (Martin Garcia et al., 2003), seasonality (Sansoucy et al., 1985) and low degradability of cell wall components (Filya et al., 2006b; Teimouri Yansari et al., 2007). The major limitations of using these residues as ruminant feedstuff are their poor nutrient contents such as protein and vitamins and high fibers with low digestibility, low palatability and high lignin contents. Nowadays great interest has been oriented to increase by-product utilization all over the world due to economic factors and pollution. Therefore, sprouting as a simple technological method that is used to germinate seeds has been reported to improve the nutritive value of seeds (Amal et al., 2007). The adoption of this technique has enabled production of fresh forage from oats, barley, wheat and other grains (RodriguezMuela et al., 2004). Several studies on the effect of germination on seeds found that germination can increase protein, fiber, reduce tannin and phytic acid contents and increase mineral bioavailability (Rao and Prabhavathi, 1982; Hussein and Ghanem, 1999; Ghavidel and Prakash, 2007). Germination also was reported to be associated with increase of vitamin concentrations and bioavailability of trace elements and minerals (El-Adawy et al., 2004). Also, sprouting improved the protein digestibility by decreasing the anti-nutritional factors (Mahmoud and El-Anany, 2014; Rubio et al., 2002). The animal consumes the whole plant including seed and roots (Resh, 2001). Because of its aspect, color, taste and texture, it is considered a highly palatable feed that promotes digestibility of other nutrients (FAO, 2001).

This study focuses on the use of the simple process of sprouting barley grains on dried agricultural byproducts as media (olive cake and rice straw) to produce green fodder with urea solution to increase the nutritive value, palatability, digestibility, nitrogen retention, rumen characteristics and serum constituents of these by-products as fed to goats.

\section{MATERIALS AND METHODS}

The trial was carried out at the South Sinai Research Station, Desert Research Center, Sinai Peninsula, about (200 km South East of Cairo).

\section{Preparation of seeds before planting:}

Seeds were cleaned from debris and other foreign materials. Then the cleaned seeds were sterilized by soaking for 30 minutes in a $2 \%$ sodium hypochlorite solution to control the formation of mould. Planting trays were also cleaned and disinfected. The seeds were then washed well from residues of bleach and resoaked in tap water overnight (about 12 hours) before planting.

\section{Production of sprouted barley:}

Production method for grains sprouting in trays was applied as described by (Mohammadi et al., 2007) using about 7-10 cm thick layer of rice straw and olive cake as sprouting media. Cereal grains of local barley (Hordeum vulgare L.) were cleaned from debris and other foreign materials. At the end of the soaking period, soaked seeds were spread on the top of the tested media. Germination period on the media surface lasted about 15 days to get shoot sprouts, shoot length was $22-25 \mathrm{~cm}$. The $1-3 \%$ urea solution $(46.5 \% \mathrm{~N})$ on DM basis was used as a source of nitrogen fertilizer, seeding rate used in this experiment was about $15 \%$ density of the roughage media. Planting trays were irrigated with tap water once a day early in the morning to provide enough water to keep the seeds/ seedlings moist.

\section{Animals and rations:}

Twenty desert male goats (Egyptian goats breed) with an average body weight of $24.34 \pm 1.29 \mathrm{~kg}$ (18 months of age) were randomly divided into four equal groups ( 4 animals each). The experiment was lasted fourty five days in which goats were feeding one of the next dietary treatments as follow:

T1: Alfalfa (Medicago sativa) ad libitum (control).

T2: sprouted barley grains on $50 \%$ rice straw $+50 \%$ olive cake ad libitum.

T3: sprouted barley grains on $50 \%$ rice straw $+50 \%$ olive cake treated with $1 \%$ urea ad libitum.

T4: sprouted barley grains on $50 \%$ rice straw $+50 \%$ olive cake treated with $2 \%$ urea ad libitum.

T5: sprouted barley grains on $50 \%$ rice straw $+50 \%$ olive cake treated with $3 \%$ urea ad libitum.

A feeding experiment followed by a metabolism trial was conducted.

\section{Digestibility trial:}

At the end of the feeding period, animals of were subjected to the metabolism trial, that was lasted for 10-day adaptation period followed by 5-day collection period. 
During the collection period, total fecal and urine were daily collected and sampled (10\% by weight of daily samples). Daily water intake was available twice daily and recorded. At the end of the collection period, rumen liquor was sampled by a stomach tube at 0,3 and 6 hours after feeding. Blood samples also were taken from jugular vein after feeding.

\section{Chemical analysis:}

The dry matter (DM) and crude protein (CP) were determined according to A.O.A.C. (1997). The neutral detergent fiber (NDF), acid detergent fiber (ADF) and acid detergent lignin (ADL) were determined according to Goering and Van Soest (1970). Rumen total volatile fatty acids (TVFA's) were (Warner, 1964) and ammonia nitrogen values were also evaluated. Sodium (Na) and potassium (K) were determined by using the standard flame photometer (Jackson, 1958). Blood serum samples were assayed for total protein (Armstrong and Carr, 1964) and albumin (Doumas et al., 1971), while globulin was calculated by the difference between. Serum creatinine (Henry, 1965) and urea (Patton and Crouch, 1977) were also determined. All blood serum analysis were estimated using Jenway spectrophotometer (UK).

\section{Statistical analysis:}

Collected data were analyzed using the general linear models (SAS, 1998). The used design was one way analysis of variance and differences between mean values were compared by (Duncan, 1955).

\section{RESULTS AND DISCUSION}

\section{Chemical composition of the tested rations:}

The chemical compositions of different tested feeds are shown in Table 1. Sprouted barley grains on $50 \%$ rice straw $+50 \%$ olive cake treated with $3 \%$ urea solution (T5) showed higher contents of $\mathrm{CP}, \mathrm{EE}$, sodium and potassium compared to T2, T3 and T4. On the other hand, the lowest values of CP, EE, GE, sodium and potassium were recorded by T2, while alfalfa (T1) had the highest values of CP, NFE, GE, sodium and potassium compared with the four treatments. The improvement in sprouted mixtures may be attributed to increase the activity of sprouted barley seed hydrolytic enzymes which catabolized starch to soluble sugars for use in respiration and cell-wall synthesis during the germination and early stage of plant growing and lead to improvements in chemical composition of sprouted barley grains on olive cake and rice straw (Chavan and Kadam, 1989).

Table (1): Chemical composition of the experimental diets.

\begin{tabular}{|c|c|c|c|c|c|}
\hline \multirow[t]{2}{*}{ Item } & \multicolumn{5}{|c|}{ Experimental diets } \\
\hline & $\mathrm{T} 1$ & $\mathrm{~T} 2$ & T3 & $\mathrm{T} 4$ & T5 \\
\hline \multicolumn{6}{|c|}{ Chemical composition, \% of DM } \\
\hline Organic matter & 83.79 & 84.64 & 83.92 & 84.30 & 83.63 \\
\hline Crude protein & 13.85 & 7.93 & 9.96 & 10.24 & 11.27 \\
\hline Crude fat & 2.51 & 2.20 & 2.35 & 2.52 & 2.67 \\
\hline Nitrogen free extract & 42.88 & 40.86 & 40.31 & 41.04 & 39.96 \\
\hline Neutral detergent fiber & 45.00 & 68.42 & 67.09 & 64.19 & 63.40 \\
\hline Acid detergent fiber & 32.00 & 41.40 & 40.74 & 39.56 & 37.07 \\
\hline Acid detergent lignin & 10.33 & 16.43 & 15.43 & 13.40 & 12.13 \\
\hline Cellulose & 21.67 & 24.97 & 25.31 & 26.16 & 24.94 \\
\hline Hemicellulose & 13.00 & 27.02 & 26.35 & 24.63 & 26.33 \\
\hline $\mathrm{GE} \mathrm{Mcal} / \mathrm{kg} \mathrm{DM}^{1}$ & 381.68 & 374.70 & 375.55 & 378.44 & 377.99 \\
\hline Sodium & 0.430 & 0.186 & 0.196 & 0.210 & 0.220 \\
\hline Potassium & 0.606 & 0.156 & 0.166 & 0.176 & 0.180 \\
\hline
\end{tabular}

In this connections, during germination occur some biochemical changes such as DM and starch content decrease and $\mathrm{CP}, \mathrm{CF}$, ash contents increase. Also carbohydrates were assimilated for metabolic activity during germination. The metabolic energy is used for growth and development with this biochemical process. Because the dry matter could not be substituted by the photosynthesis, sprout weight 
is decreased by the time photosynthesis accelerate (Anonim, 2011). Additionally, $\beta$-amylase activity that hydrolyzes the starch into simple carbohydrate was increased (Suda et al., 1986). Starch in cotyledon was broken down into smaller molecules such as glucose and fructose to provide energy for cell division while the seeds mature and grow (Vidal-Valverde et al., 2002 and Nonogaki et al., 2010). Researchers in many ways reported that DM content of the seeds is decreased while CP content increased during the sprouting (Tudor et al., 2003; Fayed, 2011; Fazeli et al., 2012; Helal, 2012 and 2015).

\section{Voluntary feed intake, mineral intake and water consumption rate:}

Dry matter intake, crude protein intake $(\mathrm{Kg})$, minerals intake $(\mathrm{g} / \mathrm{kg} \mathrm{BW})$, water consumption $(\mathrm{ml} / \mathrm{kg}$ $\mathrm{BW}$ ) and body weight (kg) are presented in Table (2) and Figure (1). Goats fed on T5 recoded the highest $(\mathrm{P} \leq 0.05)$ values of DMI $(44.82 \mathrm{~g} / \mathrm{kg} \mathrm{BW})$ followed by T4, T1, T3 and T2 in descending order, the highest values of DMI due to the higher palatability for sprouted barley grains on $50 \%$ rice straw $+50 \%$ olive cake treated with urea solution compared with control group.

Table (2): Nutrients intake by goats fed the experimental diets.

\begin{tabular}{|c|c|c|c|c|c|c|c|}
\hline \multirow[t]{2}{*}{ Item } & \multicolumn{5}{|c|}{ Treatments } & \multirow[b]{2}{*}{ SEM } & \multirow[b]{2}{*}{ Sig. } \\
\hline & $\mathrm{T} 1$ & $\mathrm{~T} 2$ & T3 & $\mathrm{T} 4$ & T5 & & \\
\hline \multicolumn{8}{|l|}{ Intake, $\mathrm{g} / \mathrm{kg} \mathrm{BW}$} \\
\hline Dry matter & $41.71^{\mathrm{abc}}$ & $38.92^{\mathrm{c}}$ & $40.94^{\mathrm{bc}}$ & $42.34^{\mathrm{ab}}$ & $44.82^{\mathrm{a}}$ & 0.973 & * \\
\hline Crude protein & $5.77^{\mathrm{a}}$ & $4.03^{\mathrm{c}}$ & $4.07^{\mathrm{c}}$ & $4.34^{\mathrm{c}}$ & $5.05^{\mathrm{b}}$ & 0.124 & $* *$ \\
\hline Sodium & $0.156^{\mathrm{a}}$ & $0.080^{\mathrm{c}}$ & $0.090^{\mathrm{bc}}$ & $0.093^{\mathrm{bc}}$ & $0.096^{\mathrm{b}}$ & 0.004 & $* *$ \\
\hline Potassium & $0.223^{\mathrm{a}}$ & $0.066^{\mathrm{b}}$ & $0.076^{\mathrm{b}}$ & $0.076^{\mathrm{b}}$ & $0.076^{\mathrm{b}}$ & 0.004 & $* *$ \\
\hline Water consumption $(\mathrm{ml} / \mathrm{kg}$ & 180.79 & 167.50 & 171.73 & 162.73 & 168.42 & 8.675 & ns \\
\hline \multicolumn{8}{|l|}{ BW) } \\
\hline \multicolumn{8}{|l|}{ Body weight (kg) } \\
\hline Initial & 24.50 & 24.00 & 24.00 & 24.50 & 24.70 & 1.290 & ns \\
\hline Final & 26.50 & 25.23 & 25.50 & 26.20 & 26.60 & 0.571 & ns \\
\hline BW changes & 2.00 & 1.23 & 1.50 & 1.70 & 1.90 & 0.667 & $\mathrm{~ns}$ \\
\hline
\end{tabular}

T1: Alfalfa (Medicago sativa) (control), T2: sprouted barley grains on 50\% rice straw $+50 \%$ olive cake, T3: sprouted barley grains on $50 \%$ rice straw $+50 \%$ olive cake treated with 1\% urea, T4: sprouted barley grains on 50\% rice straw $+50 \%$ olive cake treated with $2 \%$ urea, T5: sprouted barley grains on 50\% rice straw $+50 \%$ olive cake treated with $3 \%$ urea. ${ }^{*} P \leq 0.05, * * P \leq 0.01$, ns: non-significant; a,b,c Means with different superscripts in the same raw are significantly different at $(P \leq 0.05)$ or $(P \leq 0.01)$.

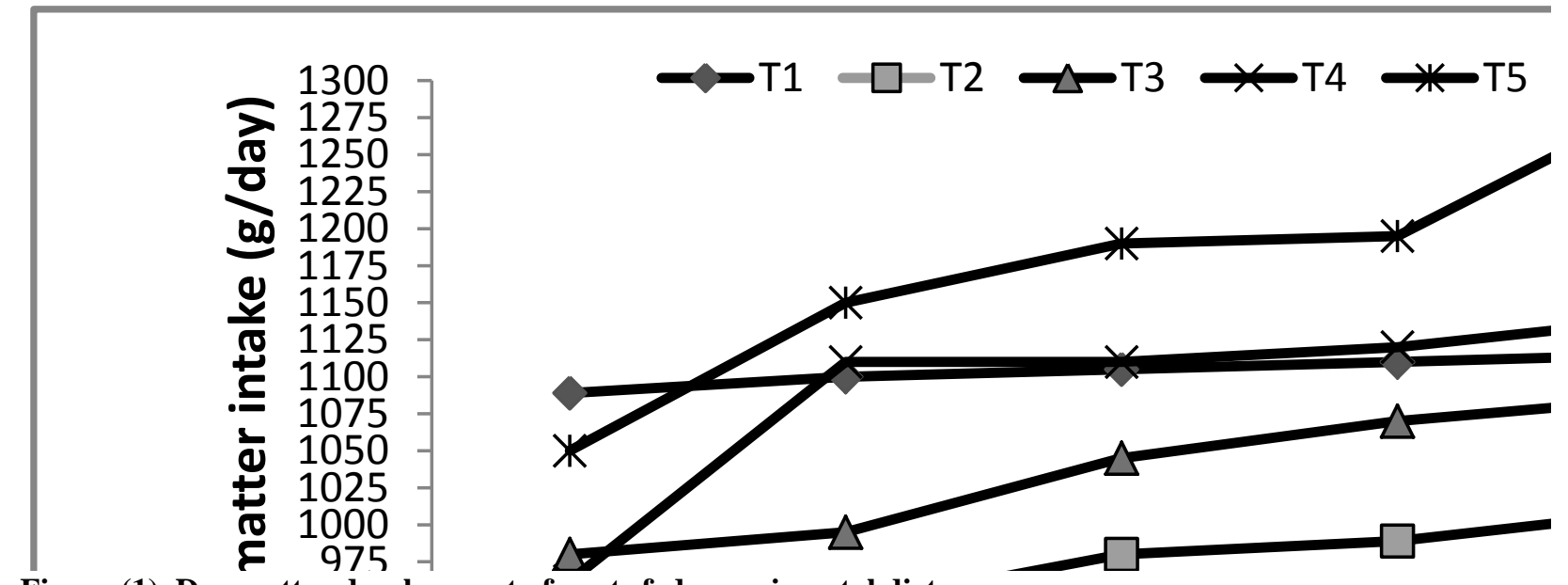

Figure (1). Dry matter development of goats fed experimental diet

T1: Alfalfa (Medicago sativa) (control), T2: sprouted barley grains on 50\% rice straw $+50 \%$ olive cake, T3: sprouted barley grains on $50 \%$ rice straw $+50 \%$ olive cake treated with 1\% urea, T4: sprouted barley grains on $50 \%$ rice straw $+50 \%$ olive cake treated with $2 \%$ urea, T5: sprouted barley grains on $50 \%$ rice straw $+50 \%$ olive cake treated with $3 \%$ urea.

These results were agreement with Eshtayeh (2004) who found that highest DM intake detected by awassi ewes fed barley hydroponic fodder; the same trend was reported by Fazeli et al. (2011) who showed that male calves fed $22.8 \%$ barley hydroponic fodder supplement in their daily ration could be due to the high palatability of barley hydroponic fodder, in addition Gunun et al. (2013) indicated that 
urea treated straw was highly palatable, the increase in palatability might be due to the blending and processing of less palatable fibrous straw (Jaglan and Kishore, 2005), which may partially explain our observed increase in DM and nutrient intake. CP intake g/kg BW was significantly ( $\mathrm{P} \leq 0.01)$ high in animals fed $\mathrm{T} 1$ followed by those fed $\mathrm{T} 5$ and the lowest was $\mathrm{T} 2$, respectively. This finding related to the high content of CP in Alfalfa. The lowest significant of water consumption was recorded by goats fed T4 $(162.73 \mathrm{ml} / \mathrm{kg} \mathrm{BW})$ as compared with other treatments, the reduction in water consumption may be due to the animal's water recovery potential from the sprouted green fodder. These results were agreement with Fazeli et al. (2011) and Weldegerima (2015). Minerals intake g/kg BW was summarized in table 2. Sodium and Potassium are mainly involved in maintenance of osmotic pressure and acid balance in the body (McDowell, 1997).This greatest concentrations of Sodium and Potassium intake g/kg BW were reported in alfalfa followed by $\mathrm{T} 5$ and the lowest was $\mathrm{T} 2$. These results were agreement with Mbaeyi and Onweluzo (2010) who showed significant increase $(\mathrm{P} \leq 0.05)$ in phosphorus, sodium and potassium content of sprouted samples.

\section{Nutrient digestion coefficients and Nitrogen balance:}

Digestibility coefficients, nutritive values and nitrogen balance are shown in Table 3. Goats fed T5 recorded the highest $(\mathrm{P} \leq 0.01)$ digestibility coefficients of $\mathrm{EE}, \mathrm{NDF}$ and hemicellulose compared with other groups. Highest digestibility coefficients of $\mathrm{CP}$ was recorded by animals fed $\mathrm{T} 1$ and $\mathrm{T} 5$ being 75.06 and $73.49 \%$; respectively with no significantly differences between $\mathrm{T} 3$ and $\mathrm{T} 4$, while the lowest $(\mathrm{P} \leq 0.05)$ digestibility coefficients of $\mathrm{CP}$ was recorded by $\mathrm{T} 2$. These results agree with that obtained by Fayed (2011), Helal (2012), Helal and Mona (2013a), Helal and Mona (2013b) and Helal (2015) who found that the digestibility coefficients of all nutrients for sprouted barley on tested roughages were higher than that of untreated. This may be attributed to fresh grains sprouts have been reported to have highly soluble protein and amino acids in response to the enzymatic transformations during early plant growth (Chung $e t$ al., 1989 and Dikshit and Ghadle, 2003).

Table (3): Digestibility coefficient, nutritive values and nitrogen balance of the experimental diets.

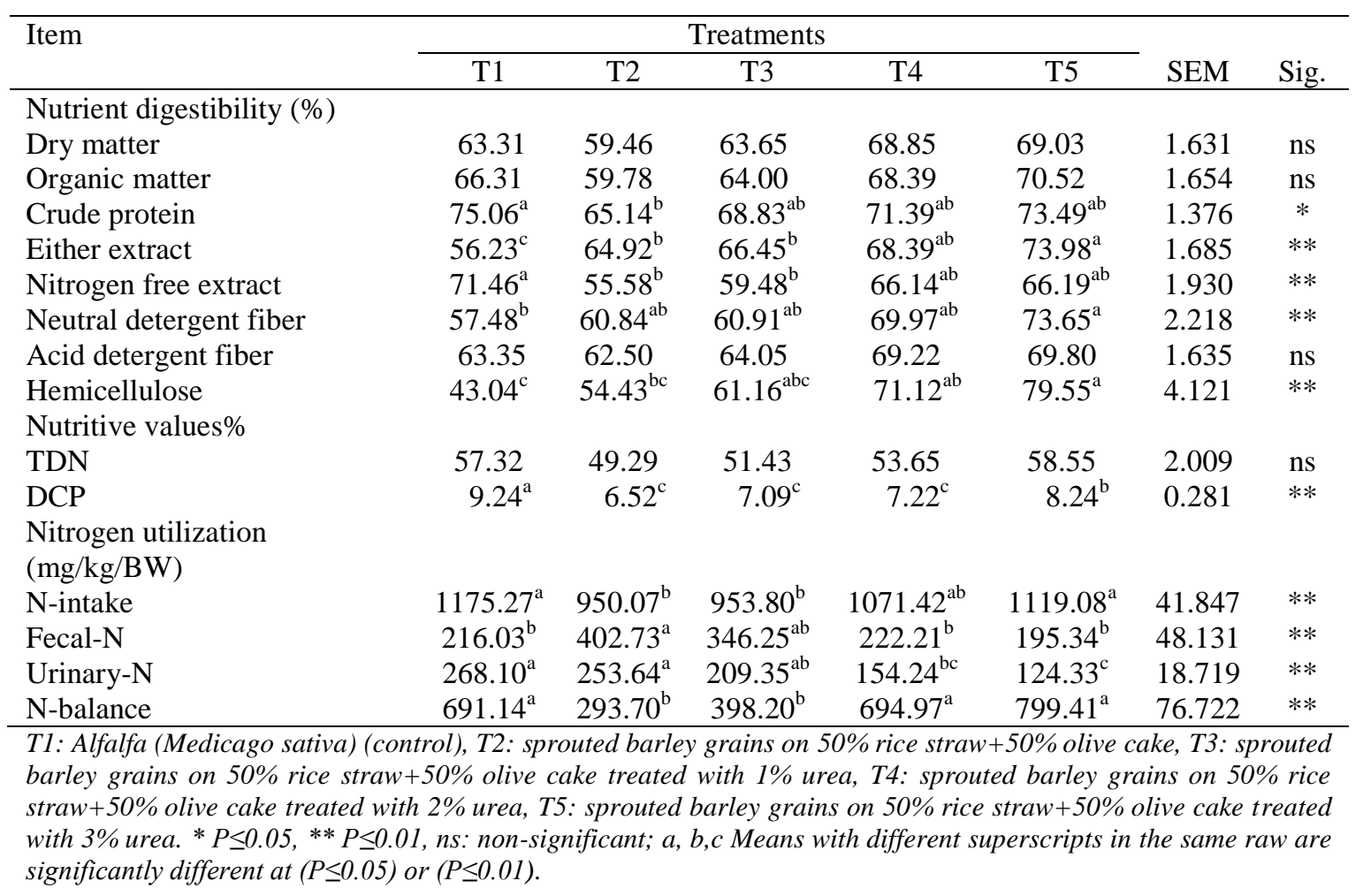

Moreover, Abbase (2009) reported that vegetated barley is rich in $\beta$-gluconase enzymes which led to hydrolysis of carbohydrates complex to simpler nutrients. Also, there was an increase in OM digestibility for T3, T4 and T5 by 63.65, 68.85 and $69.03 \%$ respectively, compared with Alfalfa diet. While, there were no significant differences in the OM digestibility among the five experimental groups. This could be explained on the basis that vegetation process improved the digestibility and nutritive values of rice straw as bedding material Abbase (2009). In this respect, Gunun et al. (2013) who reported that 3\% urea-treated 
rice straw (UTRS) could improve digestibility of DM, OM, and CP, which may have been due to the higher CP content in the UTRS and enhanced CP intake. Also, Shoukry et al. (1993) and Yacoyt et al. (2007) reported that urea treatment of poor quality roughages increased digestibility or degradability of cell wall constituents. Moreover, NDF and ADF digestibility was higher for UTRS than for RS. Resulting in an increased surface area available for attack by rumen microorganisms and thus increasing the rate of breakdown and the rate of passage of treated straw through the digestive tract (Goto and Yokoe, 1996 and Ha et al., 2001).

Nutritive values expressed as TDN\% and DCP\%; the highest TDN\% value was recorded by animals fed T5 (58.55\%) followed by T1, T4, T3 and the lowest value was for T2. Highest ( $\mathrm{P} \leq 0.01) \mathrm{DCP} \%$ was $9.24 \%$ which recorded by $\mathrm{T} 1$ followed by $\mathrm{T} 5, \mathrm{~T} 4, \mathrm{~T} 3$ and $\mathrm{T} 2$, respectively. These results may be attributed to higher CP digestibility coefficients of animals fed T1 and T5. It also could be due to the improvement of nutrient quality, because of the ability of sprouted germinated plants to transport nutrients to the roots to meet the requirement for strong healthy vegetative growth, besides increasing protein, vitamins and minerals content during process (Shipared, 2005 and Dung et al., 2010).

Data of N-balance recorded for the five experimental groups are reported in Table 3. Higher values of nitrogen intake were recorded by T1 (1175.27) followed by T5 (1119.08) and T4 (1071.42) with insignificant differences. Higher nitrogen intake may due to high content of crude protein in T1, T4 and T5 (Table 1). Lowest $(\mathrm{P} \leq 0.01)$ values of fecal nitrogen and urinary nitrogen were recorded by $\mathrm{T} 5$ being 195.34 and $124.33(\mathrm{mg} / \mathrm{kg} / \mathrm{BW})$; respectively compared with other groups. Animals fed the T5 and T4 recorded highest significantly $(\mathrm{P} \leq 0.01)$ of $\mathrm{N}$ balance compared with other groups. This finding may be related to higher improvement in $\mathrm{CP}$ intake and its digestibility in sprouted mixtures compared with other experimental forages. The highest nitrogen retention by feeding urea treatment could be due to the higher improvement in CP intake and digestibility and the higher utilization of urea nitrogen by goats. Therefore, these treatments improve also the intake, digestibility, feeding value and N-balance (Hassan, 2005).

\section{Minerals utilization:}

Data of Table (4) showed that Sodium and Potassium utilization revealed that $\mathrm{Na}$ intake, excretion and balance $(\mathrm{g} / \mathrm{kg} \mathrm{BW})$ were varied significantly among the experimental groups. The highest $(\mathrm{P} \leq 0.01)$ values of $\mathrm{Na}$ and $\mathrm{K}$ intake and excretion in urine were for $\mathrm{T} 1$. Highest $(\mathrm{P} \leq 0.05)$ value of $\mathrm{Na}$ balance was recorded by group fed T5; however, there were insignificant differences in $\mathrm{K}$ balance $(\mathrm{g} / \mathrm{kg} \mathrm{BW})$ between the five experimental groups. Generally, increasing metabolic enzymes of sprouting release more minerals from their bound complexes with anti-nutrient (Obizoba and Egbuna, 1991 and Nnam, 2000); thus, sprouting increased the levels of the minerals in the treated samples. Also, Morgan et al. (1992) found that ash content of sprouts increased from 2.1 in original seed (barley) to 5.3 at 8 day with increasing trace minerals.

Table (4): Sodium and Potassium (g/kg/BW) utilizations for goats fed the experimental diets.

\begin{tabular}{|c|c|c|c|c|c|c|c|}
\hline \multirow[t]{2}{*}{ Item } & \multicolumn{5}{|c|}{ Diets } & \multirow[b]{2}{*}{ SEM } & \multirow[b]{2}{*}{ Sig. } \\
\hline & $\mathrm{T} 1$ & $\mathrm{~T} 2$ & $\mathrm{~T} 3$ & $\mathrm{~T} 4$ & $\mathrm{~T} 5$ & & \\
\hline \multicolumn{8}{|l|}{ Sodium } \\
\hline Na-intake & $0.255^{\mathrm{a}}$ & $0.093^{\mathrm{b}}$ & $0.118^{\mathrm{c}}$ & $0.131^{\mathrm{d}}$ & $0.141^{\mathrm{e}}$ & 0.002 & $* *$ \\
\hline Excretion in feces & $0.021^{\mathrm{c}}$ & $0.044^{\mathrm{a}}$ & $0.042^{\mathrm{ab}}$ & $0.030^{\mathrm{abc}}$ & $0.028^{\mathrm{bc}}$ & 0.004 & $*$ \\
\hline Excretion in urine & $0.226^{\mathrm{a}}$ & $0.041^{\mathrm{c}}$ & $0.062^{\mathrm{b}}$ & $0.075^{\mathrm{b}}$ & $0.081^{\mathrm{b}}$ & 0.006 & $* *$ \\
\hline Na-balance & $0.008^{\mathrm{b}}$ & $0.008^{\mathrm{b}}$ & $0.014^{\mathrm{ab}}$ & $0.026^{\mathrm{ab}}$ & $0.032^{\mathrm{a}}$ & 0.007 & $*$ \\
\hline \multicolumn{8}{|l|}{ Potassium } \\
\hline $\mathrm{K}$-intake & $0.359^{\mathrm{a}}$ & $0.082^{\mathrm{c}}$ & $0.087^{\mathrm{bc}}$ & $0.094^{\mathrm{bc}}$ & $0.102^{\mathrm{b}}$ & 0.005 & $* *$ \\
\hline Excretion in feces & 0.019 & 0.033 & 0.027 & 0.025 & 0.014 & 0.005 & ns \\
\hline Excretion in urine & $0.335^{\mathrm{a}}$ & $0.045^{\mathrm{c}}$ & $0.051^{\mathrm{c}}$ & $0.054^{\mathrm{c}}$ & $0.070^{\mathrm{b}}$ & 0.003 & $* *$ \\
\hline K-balance & 0.005 & 0.004 & 0.009 & 0.015 & 0.018 & 0.005 & ns \\
\hline \multicolumn{8}{|c|}{$\begin{array}{l}\text { T1: Alfalfa (Medicago sativa) (control), T2: sprouted barley grains on 50\% rice straw }+50 \% \text { olive cake, T3: sprouted } \\
\text { barley grains on } 50 \% \text { rice straw }+50 \% \text { olive cake treated with } 1 \% \text { urea, T4: sprouted barley grains on } 50 \% \text { rice } \\
\text { straw }+50 \% \text { olive cake treated with } 2 \% \text { urea, T5: sprouted barley grains on } 50 \% \text { rice straw }+50 \% \text { olive cake treated } \\
\text { with } 3 \% \text { urea. } * P \leq 0.05, * * P \leq 0.01 \text {, ns: non-significant; a,b,c Means with different superscripts in the same raw are } \\
\text { significantly different at }(P \leq 0.05) \text { or }(P \leq 0.01) \text {. }\end{array}$} \\
\hline
\end{tabular}




\section{Rumen parameters:}

Data of rumen $\mathrm{pH}$, total volatile fatty acids (TVFA, s) and ammonia-nitrogen are presented in Table 5. It was clear that goats fed T5 recorded the highest significant $\mathrm{pH}$ value compared to the other experimental groups. The highest value of $\mathrm{pH}$ was obtained before feeding compared to time of post feeding. One of the most important factors influencing rumen $\mathrm{pH}$ is the amount of saliva buffer secretion, which is positively correlated with rumination activity Lu et al. (2005). Moreover, Van Soest (1994) reported that cellulolytic organisms grow optimally at pH 6.7 and $\mathrm{pH}$ below 6.2 inhibited the rate of digestion, decreased acetic acid and depressed cellulolytic activity. Rumen total volatile fatty acids (TVFA, s) revealed that supplemented sprouted media with $3 \%$ urea increased $(\mathrm{P} \leq 0.01)$ TVFA, s concentrations in the rumen, which increased after feeding and reaches its peak after 3 hours post feeding $(11.74 \mathrm{meq} / 100 \mathrm{ml})$. Animals fed on T5 recorded the highest value of total volatile fatty acids concentrations; it might be a reflection to rich energy and organic matter of fodder fed to small ruminants that provided higher concentrations of rumen metabolites which naturally improved rumen function and digestibility (Bonsi et al., 1995). The increase in TVFA, s concentration in animals fed sprouted barley may be due to that sprouts provide a good supply of vitamins, enzymes which serve as bioactive catalysts to assist in metabolism of feed and the release of energy (Shipard, 2005). In addition, Opera et al. (1975) reported that $\mathrm{N}$ supplementation from urea could increase the activity of rumen microbes in degrading carbohydrates (cellulose and starch) for TVFA, s production when the energy level was sufficient. These results were in accordance with those obtained by Abd EL-Nabi (2007) and Helal (2012 and 2015) who reported that dietary sprouted barley mixture increase TVFA, s in sheep rumen. Goats fed T5 recorded the highest $(\mathrm{P} \leq 0.01)$ ammonia-nitrogen compared with other experimental groups. The highest values of ammonia-nitrogen were $40.79 \mathrm{mg} / 100 \mathrm{ml}$ post feeding with 3 hours. This is may be due to its high content of CP and highest CP intake for animals fed this group (Norton, 2003). Other researchers reported an increase in rumen ammonia $\mathrm{N}$ with increase in CP supplementation (Bohnert et al., 2002 and Salisbury et al., 2004). Moreover, Highstreet et al., (2010) reported that higher ruminal NH3-N concentration occurred when steers were fed urea treated rice straw because of the relatively high levels of soluble $\mathrm{CP}$ which would likely have caused higher rumen ammonia levels particularly immediately after feeding.

Table (5). Ruminal fermentation parameters for goats fed the experimental diets

\begin{tabular}{|c|c|c|c|c|c|c|c|c|}
\hline \multirow{2}{*}{ Item } & \multirow{2}{*}{ Time } & \multicolumn{5}{|c|}{ Treatments } & \multirow{2}{*}{ SEM } & \multirow{2}{*}{ Sig. } \\
\hline & & $\mathrm{T} 1$ & $\mathrm{~T} 2$ & T3 & $\mathrm{T} 4$ & T5 & & \\
\hline \multicolumn{9}{|l|}{$\mathrm{pH}$} \\
\hline & 0 & $6.78^{\mathrm{a}}$ & $6.55^{\mathrm{b}}$ & $6.64^{\mathrm{ab}}$ & $6.69^{\mathrm{ab}}$ & $6.82^{\mathrm{a}}$ & 0.064 & $*$ \\
\hline & 3 & $6.01^{\mathrm{d}}$ & $6.09^{c}$ & $6.13^{c}$ & $6.19^{b}$ & $6.28^{\mathrm{a}}$ & 0.018 & $* *$ \\
\hline & 6 & 6.40 & 6.22 & 6.27 & 6.32 & 6.40 & 0.056 & $\mathrm{~ns}$ \\
\hline \multicolumn{9}{|c|}{ TVFA, s } \\
\hline & 0 & 5.53 & 4.78 & 5.10 & 5.27 & 6.14 & 0.520 & ns \\
\hline & 3 & $10.12^{b c}$ & $8.89^{c}$ & $9.18^{\mathrm{bc}}$ & $10.65^{\mathrm{ab}}$ & $11.74^{\mathrm{a}}$ & 0.485 & $* *$ \\
\hline & 6 & $8.62^{\mathrm{b}}$ & $6.98^{c}$ & $7.84^{\mathrm{bc}}$ & $8.86^{\mathrm{ab}}$ & $9.82^{\mathrm{a}}$ & 0.329 & $* *$ \\
\hline \multicolumn{9}{|c|}{ NH3-N } \\
\hline & 0 & $22.40^{c}$ & $22.90^{\mathrm{bc}}$ & $25.64^{\mathrm{ab}}$ & $26.52^{\mathrm{a}}$ & $27.75^{\mathrm{a}}$ & 0.921 & $* *$ \\
\hline & 3 & $39.77^{b}$ & $36.03^{\mathrm{d}}$ & $38.09^{c}$ & $39.82^{\mathrm{b}}$ & $40.79^{\mathrm{a}}$ & 0.281 & $* *$ \\
\hline & 6 & $34.10^{\mathrm{b}}$ & $31.78^{\mathrm{c}}$ & $32.70^{c}$ & $34.03^{\mathrm{b}}$ & $35.54^{\mathrm{a}}$ & 0.321 & $* *$ \\
\hline
\end{tabular}

T1: Alfalfa (Medicago sativa) (control), T2: sprouted barley grains on 50\% rice straw $+50 \%$ olive cake, T3: sprouted barley grains on 50\% rice straw $+50 \%$ olive cake treated with 1\% urea, T4: sprouted barley grains on 50\% rice straw $+50 \%$ olive cake treated with $2 \%$ urea, T5: sprouted barley grains on $50 \%$ rice straw $+50 \%$ olive cake treated with $3 \%$ urea. $* P \leq 0.05, * * P \leq 0.01$, ns: non-significant; a,b,c Means with different superscripts in the same raw are significantly different at $(P \leq 0.05)$ or $(P \leq 0.01)$.

Data of serum constituents of studied goats as affected by sprouting barley seeds on studied mixtures are given in Table 6. Total protein $(\mathrm{g} / \mathrm{dl})$, creatinine $(\mathrm{mg} / \mathrm{dl})$, albumin $(\mathrm{g} / \mathrm{dl})$, globulin $(\mathrm{g} / \mathrm{dl})$ and Serum urea-N were significantly $(\mathrm{P} \leq 0.01)$ elevated by treatments. Goats fed $\mathrm{T} 5$ increased $(\mathrm{P} \leq 0.01)$ serum total proteins, albumin, creatinine and Serum urea-N compared with other experimental groups. The highest level of globulin by sprouted barely treatments may indicate good developed immunity status (Ibrahim et al., 2001). This is in accordance with those reported by Kumar et al. (1980) who found a positive correlation between dietary protein and plasma protein concentration. Also, means of serum creatinine increased $(\mathrm{P} \leq 0.01)$ with $\mathrm{T} 5$. This was probably due to the high level of CP content in T5. These results are in harmony with those reported by Fayed (2011) and Helal (2012). Additionally, Elisabetta et al. 
(2009) introduced integration with hydroponically germinating oat in partial substitution of the complete feed does not modify biochemical and hematological parameters and seems to produce an improvement in animal. Generally, ruminal ammonia nitrogen $(\mathrm{NH} 3-\mathrm{N})$ and blood urea nitrogen (BUN) were increased $(\mathrm{P}<0.01)$ by urea treatment (Gunun et al., 2013).

Table (6): Blood parameter for goats fed the experimental diets.

\begin{tabular}{|c|c|c|c|c|c|c|c|}
\hline \multirow{2}{*}{ Item } & \multicolumn{5}{|c|}{ Treatments } & \multirow[b]{2}{*}{ SEM } & \multirow[b]{2}{*}{ Sig. } \\
\hline & $\mathrm{T} 1$ & $\mathrm{~T} 2$ & T3 & $\mathrm{T} 4$ & T5 & & \\
\hline Total protein $\mathrm{g} / \mathrm{d}$ & $7.65^{\mathrm{a}}$ & $6.20^{\mathrm{c}}$ & $6.67^{b}$ & $7.36^{\mathrm{a}}$ & $7.53^{\mathrm{a}}$ & 0.150 & $* *$ \\
\hline Albumin g/d & $3.41^{\mathrm{abc}}$ & $3.19^{c}$ & $3.28^{\mathrm{bc}}$ & $3.48^{\mathrm{ab}}$ & $3.62^{\mathrm{a}}$ & 0.070 & $* *$ \\
\hline Globulin g/d & $4.24^{\mathrm{a}}$ & $3.01^{\mathrm{c}}$ & $3.39^{\mathrm{bc}}$ & $3.88^{\mathrm{ab}}$ & $3.91^{\mathrm{ab}}$ & 0.189 & $* *$ \\
\hline Urea $\mathrm{mg} / \mathrm{d}$ & $33.45^{\mathrm{b}}$ & $32.20^{\mathrm{c}}$ & $32.90^{\mathrm{bc}}$ & $33.75^{\mathrm{ab}}$ & $34.69^{\mathrm{a}}$ & 0.354 & $* *$ \\
\hline Creatinine mg/d & $1.33^{\mathrm{b}}$ & $1.17^{\mathrm{c}}$ & $1.21^{\mathrm{c}}$ & $1.32^{\mathrm{b}}$ & $1.43^{\mathrm{a}}$ & 0.015 & $* *$ \\
\hline
\end{tabular}

T1: Alfalfa (Medicago sativa) (control), T2: sprouted barley grains on 50\% rice straw $+50 \%$ olive cake, T3: sprouted barley grains on $50 \%$ rice straw $+50 \%$ olive cake treated with 1\% urea, T4: sprouted barley grains on 50\% rice straw $+50 \%$ olive cake treated with $2 \%$ urea, T5: sprouted barley grains on 50\% rice straw $+50 \%$ olive cake treated with $3 \%$ urea. $* P \leq 0.05, * * P \leq 0.01$, ns: non-significant; a,b,c Means with different superscripts in the same raw are significantly different at $(P \leq 0.05)$ or $(P \leq 0.01)$.

\section{CONCLUSION}

From the results of the present study, goats could be fed on sprouted barley grains on agricultural byproducts (rice straw) and agro-industrial by-products (olive cake) treated with urea solution, without any bad effect on feed utilization.

\section{REFERENCES}

A.O.A.C. (1997). Official Methods of Analysis. $16^{\text {th }}$ Ed. Assoc. Office. Anal. Chem., Arlington, VA.

Abate D. and S. Melaku (2009). Effect of supplementing urea-treated barley straw with lucerne or vetch hays on feed intake, digestibility and growth of Arsi Bale sheep. Trop. Anim. Health Prod. 41:579586.

Abbase, H. (2009). Effect of germinated barley of some parameters productive of broilers. Egypt. J. Nutri. and feeds, 12 (3): 733-734.

Abd El-Nabi, Haiam E. (2007). Using sprouted barley and fenugreek on rice straw to replace berseem hay in growing lamb rations. MSc. Thesis, Fac. of Agri Cairo University, Egypt.

Al-Asfour, O.N. (2009). Effect of biological treatments on nutritive value of some agricultural byproducts. M.Sc. Thesis, Fac. Agric., Ain Shams Univ., Cairo, Egypt.

Amal, B.K; Z. Aurang; B. Nizakat; A.K. Shahid and S.K. Mohammad (2007). Influence of germination techniques on phytic acid and polyphenols content of chickpea (Cicer arietinum L.) sprouts. Food Chem. 104: 1074-1079.

Anonim (2011). Hydroponic fodder production. An analysis of practical and commercial opportunity. The New Zealand Merino Company.

Armstrong, W.D. and C.W. Carr (1964). Physiological chemistry. Laboratory Direction, $3{ }^{\text {rd }}$ ed., P. 75, Burges bublishing Co. Minneapolis, Minnestota. Artificially grown barley fodder by Sheep. Indian J. Small Rumen, 4 (2): 63-68.

Blaxter, K.L. (1968). The energy metabolism of ruminants. $2^{\text {nd }}$ Ed. Hutchinson and Co. Lted. London.

Bohnert, D.W.; C.S. Schauer; S.J. Falck and T. DelCurto (2002). Influence of rumen protein degradability and supplementation frequency on steers consuming low-quality forage: I. Ruminal fermentation characteristics. J. Anim. Sci., 80: 2978-2988.

Bonsi, M.L.K.; P.O. Osuji and A.K. Thuah (1995). Effect of supplementing tef straw with different level of leucaena or sasbania on the degradability of tef straw, sesbania, leucaena, tagaste and vernonia and certain rumen and blood metabolites in Ethopianmenz sheep. Anim. Feed Sci Technol 52: 101-129. 
Chavan, J. and S.S. Kadam (1989). "Nutritional improvement of cereals by sprouting." Critical Reviews in Food Science and Nutrition, 28 (5): 401-437.

Chemjon, P.B. (1991. Economic value of urea-treated straw fed to lactating buffaloes during the dry season in Nepal. Trop. Anim. Health Prod. 23:147-154.

Chung, T.; E.N. Nwokolo and J.S. Sim (1989). Compositional and digestibility changes in sprouted barley and canola seeds. Plant Foods for Human Nutrition, 39: 267-278.

Dikshit, M. and Ghadle (2003). Effect of sprouting on nutrients, anti-nutrients and in vitro digestibility of MACS.13 soybean variety. Plant Food Hum. Natr, 58: 1-11.

Doumas, B.; W. Wabson and H. Biggs (1971). Albumin standards and measurement of serum with bromocresol green. Clin, Chem., Acta.

Duncan, D.B. (1955). Multiple ranges and multiple. F. Tests Biometrics. 11: 1-42.

Dung D.D.; I.R. Godwin and J.V. Nolan (2010). Digestive characteristics, ammonia nitrogen and volatile fatty acids levels, in sheep fed oaten chaff supplemented with grimmett barley grain, freeze-dried or fresh barley sproutes. Journal of animal and veterinary Advances, 9(19): 2493-2501.

EEAA (2008). Egyptian Environmental Affairs Agency, Ministry State for Environmental Affairs- Rice Straw Utilization Program Report.

El-Adawy, T.A.; E.H. Rahma; A.A. El-Bedawey and A.E. El-Beltagy (2004). Nutritional potential and functional properties of germinated mung bean, pea and lentil seeds. Plant Foods for Human Nutrition, 58 (3): 1-13.

El-Gammal, M.I. and A.A. Shakour (2001). Emission of pollutants from harvest and burning of rice straw in Egypt villages (North East of Nile Delta). J.Union Arab. Biol., 15 (A): 191-206.

Elisabetta, M.; R. Marco; M. Fabrizio; R. Giuseppe; M. Giuseppe and Z. Antonia (2009). Improvement of sheep welfare and milk production fed on diet containing hydroponically germinating seeds. Ital. J. Anim. Sci., 8: 634- 636.

Eshtayeh and F.A. Intissar (2004). A new source of fresh green feed (Hydroponic barley) for awassi sheep. Master in environmental sciences, faculty of graduate studies, at An-Najah National University, Nablus, Palestine.

FAO (2001). Organización de las Naciones Unidas para la Agricultura yla Alimentación. Manual técnico forraje verde hidropónico. Santiago de Chile, Chile.

FAO (2011). FAO Achievements in Egypt. FAO Representation in Egypt. Food and agriculture organization of the United Nations. ISBN, 978-92-5-106936-3, P. 55. FAO Near East, Egypt.

Fayed, M. Afaf (2011). Comparative study and feed evaluation of sprouted barley grains on rice straw versus Tamarix Mannifera on performance of growing barki lambs in Sinai Journal of American Science, 7 (1): 954-961.

Fazaeli, H.; H.A. Golmohammadi; A.A. Shoayee; N. Montajebi and Sh. Mosharraf (2011). Performance of feedlot calves fed hydroponics fodder barley J. Agr. Sci.Tech., 13: 367-375.

Fazaeli, H.; H.A. Golmohammadi; S.N. Tabatabayee and M. Asghari-Tabrizi (2012). Productivity and nutritive value of barley green fodder yield in hydroponic system. J. Agr. Sci. Tech., 16 (4): 531-539.

Filya, I.H. Hanoglu; Ö. Canbolat and E. Sucu (2006b). Researches on feed value and using possibilities in lamb fattening of dried olive-cake 1. Effects on fattening performance of lambs. Uludag. Üniv. Zir.Fak. Derg., 201: 13-23.

Ghavidel, R.A. and J. Prakash (2007). The impact of germination and dehulling on nutrients, antinutrients, in vitro iron and calcium bioavailability and in vitro starch and protein digestibility of some legume seeds. LWT, 40 (7): 1292-1299.

Goering, H.K. and P.J. Van Soest (1970). Forage fiber analysis. Agricultural Handbook, No. 379, USDA, Washington. DC, USA.

Goto, M. and Y. Yokoe (1996). Ammoniation of barley straw. Effect on cellulose crystallinity and waterholding capacity. Anim. Feed Sci. Tech., 58:239-247. 
Gunun, P. Wanapat M. and Anantasook N. (2013). Effects of physical form and urea treatment of rice straw on rumen fermentation, microbial protein synthesis and nutrient digestibility in dairy steers Asian Australas. J. Anim. Sci., 26: 1689-1697.

Ha, J.K.; S.S. Lee; S.W. Kim; InK. Han; K. Ushida and K.J. Cheng (2001). Degradation of rice straw by rumen fungi and cellulolytic bacteria through mono-, co-or sequential- cultures. Asian-Aust. J. Anim. Sci., 14: 797-802.

Hanafi, E.M.; H.H. El Khadrawy; W.M. Ahmed and M.M. Zaabal (2012). Some observation on rice straw with emphasis on updates of its management. World Appl. Sci. J., 16: 354-361.

Hart, F.J. and M. Wanapat (1992). Physiology of digestion of urea-treated rice straw in swamp buffaloes. Asian-Aus. J. Anim. Sci., 5: 617-622.

Hassan, A.A. M.H.M. Yacout; M.KK. Mohsen; M.I. Bassiouni and M. Abd El-All (2005). Banana wastes (Musa acuminate L.) silage treated biologically or with urea for dairy cows feeding. Egyptian J.Nutr. and Feeds, 8 (1) Special Issue: 49-61.

Helal, H.G. (2015). Sprouted barley grains on olive cake and barley straw mixture as goat diets in Sinai. Adv. Environ.biol., 9 (22), 91-102.

Helal, H.G. (2012). Sprouted barley grains on rice straw and Acacia saligna and its effect on performance of growing barki lambs in Sinai. Proc. of the 5th Animal Wealth Research Conf. in the Middle East \& North Africa, 1-3: 331-346.

Helal, H.G. and Hassan Mona, M. (2013a). Sprouted zea mays on date palm leaves and potatoes peel waste mixture and its effects on performance of desert goats under dry season in Sinai. J.Animal and poultry prod., Mansoura Univ., 4(3):117-132.

Helal, H.G. and Hassan Mona, M. (2013b). Effect of sprouted corn grains on leucaena tree pruning and olive tree pruning diets for desert goats under Sinai condition. J.Animal and Poultry Prod., Mansoura Univ., 4(3): 133-147.

Henry, R.J. (1965). Clinical Chemistry. Principles and Technics, P. 293.

Highstreet, A.; P.H. Robinson; J. Robison and J.G. Garrett (2010). Response of holstein cows to replacing urea with a slowly rumen released urea in a diet high in soluble crude protein. Livestock Sci., 129:179-185.

Hussein, L.; and K.Z. Ghanem (1999). Calcium bioavailability from selected Egyptian foods with emphasis on the impact of germination and fermentation. International Journal of Food Sciences and Nutrition, 50(5): 351-356.

Ibrahim Fathia, A.; El-Hosseiny Hoda, M.; and I.M. El-Sayed (2001). Effect of using sprouted barley by recycle process of agriculture residues on feeding value, rumen activity and some blood constituents of crossbred sheep. Egyptian J. Nutrition and feeds, 4 (Special Issue): 265-273.

Information Center of South Sinai Governorate (2014). Agricultural Department, Information Center of South Sinai Governorate. El-Tour, Egypt, March, 2014.

Jackson, M.L. (1958). Soil Chemical Analysis. Constable and Company, Ltd, England.

Jaglan, B.S. and N. Kishore (2005). Compaction behavior of urea treated crop residues in feed blocks. Indian J. Anim. Nutr., 22: 90-93.

Keshtkar, H. and L.L. Ashbaugh (2007). Size distribution of polycyclic aromatic hydrocarbon particulate emission factors from agricultural burning. Atmos. Environ. J., 41: 2729-2739.

Kumar, N.U.; S. Singh and D.N. Verma (1980). Effect of different levels of dietary protein and energy on growth of male buffalo calves. Ind. J. Anim. Sci., 51: 513.

Lu, C.D.; J.R. Kawas and O.G. Mahgoub (2005). Fibre digestion and utilization in goats. Small Rumin. Res., 60: 45-52.

Mahmoud, A.H.; A.M. El-Anany (2014). Nutritional and sensory evaluation of a complementary food formulated from rice, faba beans, sweet potato flour, and peanut oil. Food Nutr. Bull., 35(4): 403413. 
Martín García, A.I.; A. Moumen; D.R. Yáñez Ruiz and E. Molina Alcaide (2003). Chemical composition and nutrients availability for goats and sheep of two-stage olive cake and olive leaves. Anim. Feed Sci. Technol., 107: 61-74.

Mbaeyi, I.E and Onweluzo, J.C. (2010). Effect of sprouting and pregelatinization on the composition and sensory properties of flaked breakfast cereal produced from sorghum-pigeon pea blens. Journal of Tropical Agriculture, Food, Environment and Extension, 9 (3): 184-192.

McDowell, L.R. (1997). Minerals for grazing ruminants in tropical regions. Anim. Sci. Department center to Tropical Agriculture University of Florida. U.S.A.

Mohammadi Thanaa, F. and M.M. F. AbdalLah (2007). Effect of four seed sprouts on rice straw and spent mushroom media of rice straw to be used as a green fodder. Egyptian J. 1. 1. Nutrition and feeds, 10 (Special Issue): 679-691.

Morgan, J.; Hunter, R.R. and O'Haire, R. (1992). Limiting factors in hydroponic barley grass production. 8th International congress on soil less culture, Hunter's Rest, South Africa. pp: 241-261.

Nefzaoui, A. (1983). Etude De L'utilisation Des Sous-produits De L'olivier En Alimentation Animale En Tunisie. Animal Production and Health.

Nnam, N.M. (2000). Evaluation of the effect of sprouting on the viscosity, proximate composition and mineral content of Hungry rice, Acha (Digitaria exilis) flours. Nigerian Food Journal, 18:57- 62.

Nonogaki, H.; Bassel, G.W. and Bewley, J.W. (2010). Germination-still a mystery. Plant Science doi:10.1016/j.plantsci.2010.02.010.

Norton, B.W. (2003). The Nutritive value of tree legumes. In: Forage Tree Legumes in Tropical Agriculture, Gutteridge R.C and Shelton H.M, (eds). pp.43.

Opera, Y.; K. Shimbayashi, and T. Yonemura. 1975. Change of ruminal properties of sheep during feeding urea diet. Jpn. J. Zootech. Sci. 46:140-145.

Obizoba, I.C. and Egbuna, H.I. (1991). Effect of germination and fermentation on the nutritional quality of bambara nut (Voandzeia Subterranean L. Thouars) and its product milk. Plant Foods for Human Nutrition 41:1-10.

Patton, C.J. and Crouch S.R. (1977). Enzymatic determination of urea by calorimetrically method Anal. Chem., 49: 464.

Rao, B.S.N. and Prabhavathi, T. (1982). Tannin content of foods commonly consumed in India and its influence on ionisable iron. Journal of the Science of Food and Agriculture, 33 (1): 89-96.

Resh, H.M. (2001). Hydroponic food production. 6th ed., 567 pp., Woodbridge Press, Santa Barbara, CA.

Rodriguez-Muela, C.; Rodriguez, H.E.; Ruiz, O.; Flores, A.; Grado, J.A. and Arzola, C. (2004). Use of green fodder produced in hydroponic system as supplement for lactating cows during the dry season. Proceedings of the American Society of Animal Science, 56: 271-274.

Rubio, L.A.; Muzquiz, M.; Burbano, C.; Cuadrado, C.; Pedrosa, M.M. (2002). High apparent leal digestibility of amino acids in raw and germinated faba bean (Vicia faba) and chickpea (Cicerarietinum) - based diets for rats. J. Sci. Food Agric., 82: 1710-1717.

Safari, J.G.; D.E. Mushi; L.A. Mtenga; G.C. Kifaro and L.O. Eik (2011). Growth, carcass yield and meat quality attributes of Red Maasai sheep fed wheat straw-based diets. Trop. Anim. Health Prod., 43:8997.

Salisbury, M.W.; C.R. krehbiel; T.T. Ross; C.L. Schultz and L.L. Melton (2004). Effects of supplemental protein type on intake, nitrogen balance and site and extent of digestion in white face wethers consuming low-quality grass hay. J. Anim. Sci., 82: 3567-3576.

Sansoucy, R.; X. Alibes; P.H. Berge; F. Martilotti; A. Nefzaoui and P.Zoïopoulos (1985). Olive byproducts for animal feed. Food and Agriculture Organization of the United Nation, Rome, FAO.

SAS (1998). User guide: statistics version 6, 4th ed., Vol. 2 SAS Institue Inc., Cary. NC. USA.

Shipard I. (2005). How can I grow and use sprouts as living food? Stewart publishing.

Shoukry, M.M. (2013). An overview on the potential of using agricultural by-products in feeding ruminants. 14 Animal nutrition the scientific conference, pp: 26-29. 
Shoukry, M.M.; F.S. Hamissa; M. Sawsan; A.H. Ahmed; H.M. El-Rafai; H.M. Ali and Z.M.Z. Abdel Motagally (1985). Nutritive improvement of some low quality roughages for ruminants. 1. Effect of different microbial and chemical treatment on the quality of sugar cane bagasse. Egypt J. Anim. Prod., 25 (2): 329-342.

Shoukry, M.M.; F.M. Salman and H.M. Ali (1993). Nutritional evaluation of urea treated bean straw, corn cobs, rice straw and peanut husk using the direct method. J. Agric. Sci. Mansoura Univ., 18: 100.

Suda, M.; Watanabe, T.; Kobayashi, M. and Matsuda, K. (1986). Changes in starch content and related enzyme activities during the growth of germinating soybeans. Agricultural and Biological Chemistry, 50 (12): 3195-3196.

Teimouri Yansari, A.; H. Sadeghi; Z. Ansari-Pirsarai and H. Mohammad-Zadeh (2007). Ruminal dry matter and nutrient degradability of different olive cake by-products after incubation in the rumen using nylon bag technique. Int. J. Agric. Biol., 9: 439-442.

Tudor, G.; Darcy, T.; Smith, P. and Shallcross, F. (2003). The intake and live weight change of drought master steers fed hydroponically grown, young sprouted barley fodder (auto grass). Department of Agriculture Western Australia.

Van Soest, P.J. (1994). Nutritional ecology of the ruminant. Cornell University Press, New York, NY.

Vidal-Valverde, C.; Frias, J.; Sierra, I.; Blazquez, I.; Lambein, F. and Kuo, Y. (2002). New functional legume foods by germination: effect on the nutritive value of beans, lentils and peas. European Food Research and Technology, 215(6): 472-477.

Wanapat, M.; F. Sundstøl and T. H. Garmo (1985). A comparison of alkali treatment methods to improve the nutritive value of straw. I. Digestibility and metabolizability. Anim. Feed Sci. Technol., 12: 295309.

Warner, A.C.J. (1964). Production of volatile fatty acids in the rumen methods of measurements Nutr. Abst. and Rev., 34: 339.

Weldegerima Kide Gebremedhin (2015). Nutritional benefit and economic value of feeding hydroponically grown maize and barley fodder for konkan kanyal goats. Journal of Agriculture and Veterinary Science, 8: 24-30.

Yacoyt, M.H.M.; R. Salama and M.I.T. Elgzar (2007). Evaluation of silage made from corn stalks and its effect on lambs performance. Egyptian J. Nutritionand Feeds, 10 (2) (Special Issue): 621-633. 
تأثير تظذية حبوب الثعير المستنبت علي قش الارز وفلة الزيتون علي اداء الماعز في سيناء

حسن جودة هلال

قسم تغذية الحيوان واللو/جن- مركز بحوث الصحراءـ المطرية- مصر.

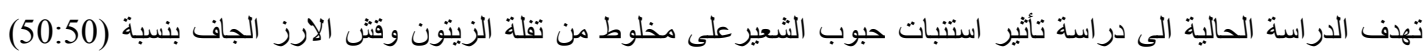

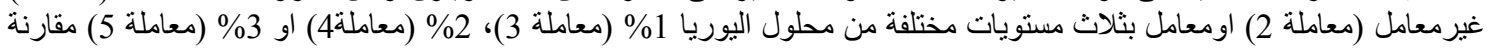

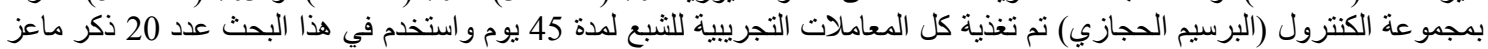

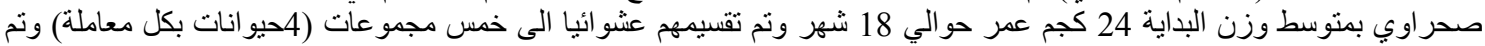

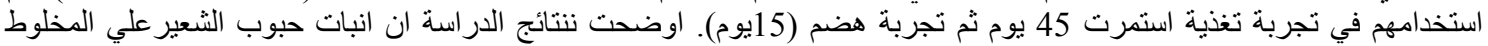

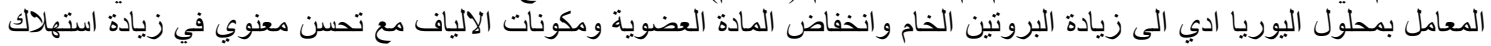

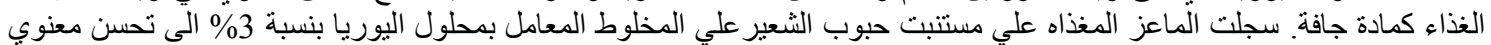

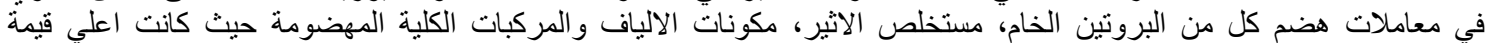

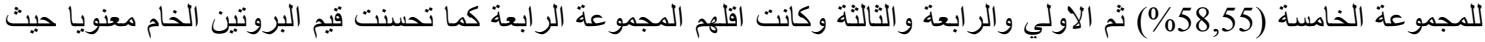

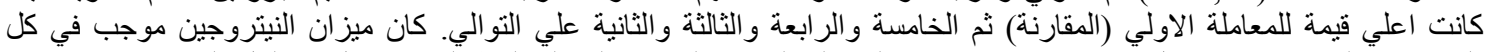

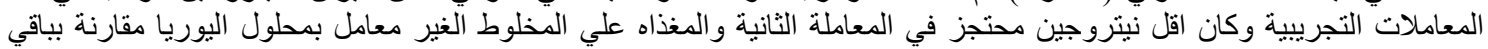

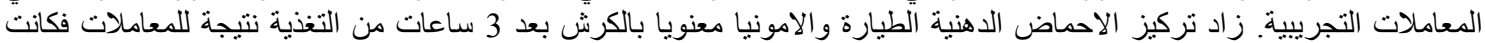

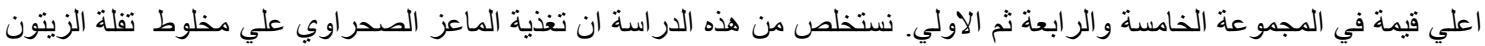

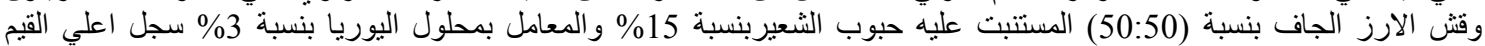

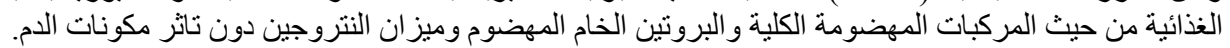

